\title{
Evaluation of Traditional Herb Extract Salvia officinalis in Treatment of Alzheimer's Disease
}

\author{
Sanjana Datta*, Shailendra Patil
}

Sanjana Datta*, Shailendra Patil

SVN Institute of Pharmaceutical Sciences, Swami Vivekanand University, Sagar (MP) 470228, INDIA.

\section{Correspondence}

Sanjana Datta

SVN Institute of Pharmaceutical Sciences, Swami Vivekanand University, Sagar (MP) 470228, INDIA.

E-mail: dattasanjanadas@gmail.com

History

- Submission Date: 28-09-2019;

- Review completed: 10-10-2019;

- Accepted Date: 12-12-2019.

DOI : 10.5530/pj.2020.12.20

Article Available online http://www.phcogj.com/v12/i1

Copyright

(C) 2020 Phcogj.Com. This is an openaccess article distributed under the terms of the Creative Commons Attribution 4.0 International license.

\begin{abstract}
Aim and Objective: Alzheimer's disease is progressive neurodegenerative disorder which affects older individuals. It is the most common cause of dementia and it is associated with the presence of senile plaques which are deposition of beta- amyloidal protein in the hippocampus area of the brain. Medicinal plants have played vital role in world health. In spite of the great advances observed in modern medicine in recent decades, plants still make an important contribution to health care. The present study is done to evaluate Salvia officinalis, for in vivo study on Alzheimer's disease induced mice. Materials and Methodology: Memory Enhancing Activity, Conditioned avoidance test, Y-maze spontaneous alternation test, Elevated Plus Maze, Morris Water Maze, Measurement of Locomotor Activity were done to assess memory \& cognitive functioning. The isolated brain homogenate is estimated for reduced glutathione content, Acetyl cholinesterase Activity, Superoxide dismutase assay (SOD), Lipid peroxidation assay (TBARS), Glutathione peroxidase assay (GSH-Px) and Histopathology examination of brain was performed and analyzed. Results and Discussion: The elevated level of enzymes and decreased level of tissue antioxidant markers were observed in treatment comparative to piracetam treatment group. While $300 \mathrm{mg} / \mathrm{kg}$ extract significantly reduced the elevated levels of the enzymes and also significantly increased the tissue antioxidant levels, while decreased the glutathione levels when compared with the control. Conclusion: The histopathological study confirmed the recovery. The herbal extract (150 and $300 \mathrm{mg} / \mathrm{kg}$ ) has shown effectiveness against Alzheimer's disease.

Key words: Salvia officinalis, Alzheimer's disease, Locomotor activity, Histopathological assessment.
\end{abstract}

\section{INTRODUCTION}

Herbal medicinal products are defined as the study or use of medicinal herbs to prevent and treat diseases and ailments or to promote health and healing (or) a drug or preparation made from a plant or plants and used for any of such purposes. The use of natural products is in human diseases such as cardiovascular disease, cancer, and neurodegenerative disease is now a fruitful supporting therapy. Alzheimer's disease is progressive neurodegenerative disorder which affects older individuals. It is the most common cause of dementia. It is associated with the presence of senile plaques which are deposition of beta- amyloidal protein in the hippocampus area of the brain. The contributing factors are not known yet, but several threads have been identified by the scientists who can link the factors like Age, Genetic history, Lifestyle, Heredity, Vascular risk factors, Head injury and Diet. The demonstration of damage to the cholinergic pathways in the brain leads to great interest in drug development. Acetylcholinesterase inhibitors are usually prescribed to treat $\mathrm{AD}$. These drugs help in enhancing cognitive functions such as memory and thoughts. These medicines are effective in patients with mild to moderate AD. Tacrine (a cholinesterase inhibitor) at a high dose (160 $\mathrm{mg} / \mathrm{d}$ ) was reportedly used in the treatment of
AD. Tacrine was investigated in both clinical trials and neuropsychological test scores, in a 30 week randomized placebo controlled trial. Anti-oxidants are effective for $\mathrm{AD}$ because they aid in reducing the free radicals that damage the brain cells. Drugs involved with the CNS may have general stimulatory or depressant action with anticonvulsant and psychopharmacological activities. Memory deficit is a major global health problem. Current therapies are inadequate and have numerous adverse effects. There is an urgent need for possible alternative treatments for $\mathrm{AD}$ and memory deficit. Various medicinal plants are prescribed to enhance the memory. We have reviewed the literature on medicinal plants used in the treatment of $\mathrm{AD}$ and memory deficit.

Herbal medicine has long been used in China as therapy for dementia. The Complete Work of Jingyue published in 1624 contains the earliest known description in the world of a herbal therapeutic strategy for dementia. In the past 10 years, however, herbal drugs have seldom been approved for use alone in treating dementia. Overall, systematic review has identified a few single herbs and herbal formulations as possible effective medicine for $\mathrm{AD}$. According to the current evidence, some of these therapies show promising results in terms of their cognitive benefits.

S. officinalis has numerous common names. Some of the best known are sage, common sage, garden sage, 
golden sage, kitchen sage, true sage, culinary sage, Dalmatian sage, and broadleaf sage. Cultivated forms include purple sage and red sage.

S. officinalis was described by Carl Linnaeus in 1753. It has been grown for centuries in the Old World for its food and healing properties, and was often described in old herbals for the many miraculous properties attributed to it. The specific epithet, officinalis, refers to the plant's medicinal use the $S$. officinalis was the traditional storeroom of a monastery where herbs and medicines were stored. S. officinalis has been classified under many other scientific names over the years, including six different names since 1940 alone. It is the type species for the genus Salvia.

The plant had a high reputation throughout the Middle Ages, with many sayings referring to its healing properties and value. It was sometimes called S. salvatrix (sage the savior) and was one of the ingredients of Four Thieves Vinegar, a blend of herbs which was supposed to ward off the plague. Dioscorides, Pliny, and Galen all recommended sage as a diuretic, hemostatic, emmenagogue, andtonic. John Gerard's Herball (1597) states that sage "is singularly good for the head and brain, it quicken the senses and memory, strengthen the sinews, restore health to those that have the palsy, and take away shake trembling of the members." In past centuries it was also used for hair care, insect bites and wasp stings, nervous conditions, mental conditions, oral preparations for inflammation of the mouth, tongue and throat, and also to reduce fevers.

According to Peter Rogers' team at Bristol University, researchers have concluded that extracts of sage can enhance cognitive performance. This was compared to the similar effect of the caffeine found in tea and coffee. Due to some of its chemical compound properties that allow it to deal with free radicals in a person's digestive system, it can be used in treating various digestive disorders such as flatulence, poor digestion, and bloating.

There was a study done in 2001 to test S. officinalis' antioxidant activities, and the results showed that rosmarinic acid, along with other chemical compounds, showed affective antioxidant activity. Antioxidant activity is important because many serious diseases such as brain dysfunction, cancer, heart diseases, and immune system decline have the possibility of resulting from cellular impairment caused by free radicals. Having high amounts of antioxidants in a person's diet may aid in disease prevention by getting rid of the free radicals.

\section{MATERIALS}

\section{Experimental animals}

Swiss albino mice (20-25 g) obtained and were maintained under standard condition in animal house. The animals were maintained under standard conditions of temperature $\left(23 \pm 2^{\circ} \mathrm{C}\right)$, humidity $(35$ $60 \%$ ), and 12:12 light and dark ratio. The animals were placed in polypropylene cages containing sterile paddy husk as bedding. They had free access to standard pellets as basal diet and water ad libitum. ${ }^{1-15}$ IAEC No: 1688/PO/E/2013/CPCSEA.

\section{Plant material}

The fresh parts of Salvia officinalis, was collected from local areas of Tirupathi, Andrapradesh, India and authenticated by Prof. Dr. K. Madhava Chetty, Assistant Professor, Department of Botany, Sri Venkateswara University, Tirupathi. The plant was dried in shade and was ground to get fine powder.

\section{METHODS}

\section{Extraction of plant material by means of counter current extraction procedure ${ }^{16}$}

This extraction process has significant advantages ${ }^{16}$ :

i) A unit quantity of the plant material can be extracted with much smaller volume of solvent as compared to other methods like maceration, decoction, and percolation.

ii) CCE is commonly done at room temperature, which spares the thermo labile constituents from exposure to heat which is employed in most other techniques.

iii) As the pulverization of the drug is done under wet conditions, the heat generated during comminution is neutralized by water. This again spares the thermo labile constituents from exposure to heat.

iv) The extraction procedure has been rated to be more efficient and effective than continuous hot extraction.

v) Prepared extracts using above methods will be vacuum dried to remove any solvent remaining.

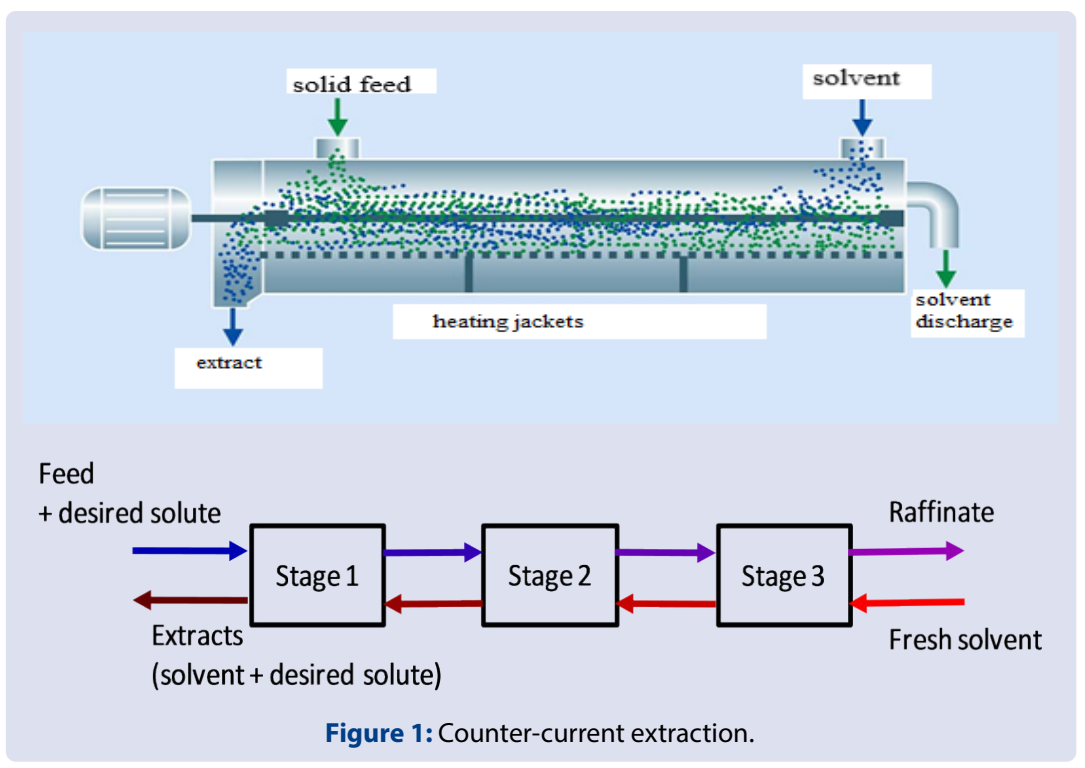




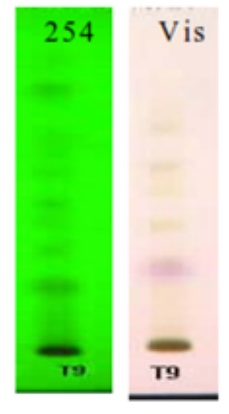

Solvent system used:

A mount applied:

Detection by :

Total number of spots:

Number of major spots:
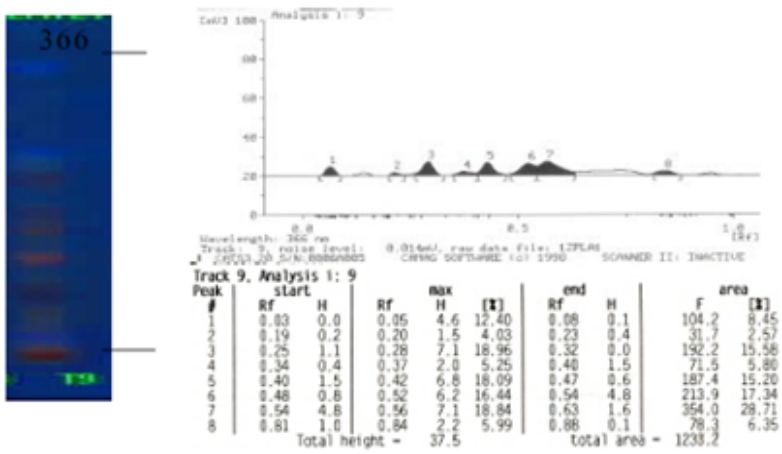

Ethyl acetate: Hexane ( $30: 70$

$10 \mu \mathrm{l}$ of $20 \mathrm{mg} / \mathrm{ml}$ solution $(0.2 \mathrm{mg})$

$254 \mathrm{~nm}, 366 \mathrm{~nm}$ and visible

4 ( Rf. $0.28,0.42,0.52,0.56$ )

Figure 2: TLC of ethanol extract of salvia officinalis detection at visible, 254 and $366 \mathrm{~nm}$ and its HPTLC densitogram detection at $366 \mathrm{~nm}$.

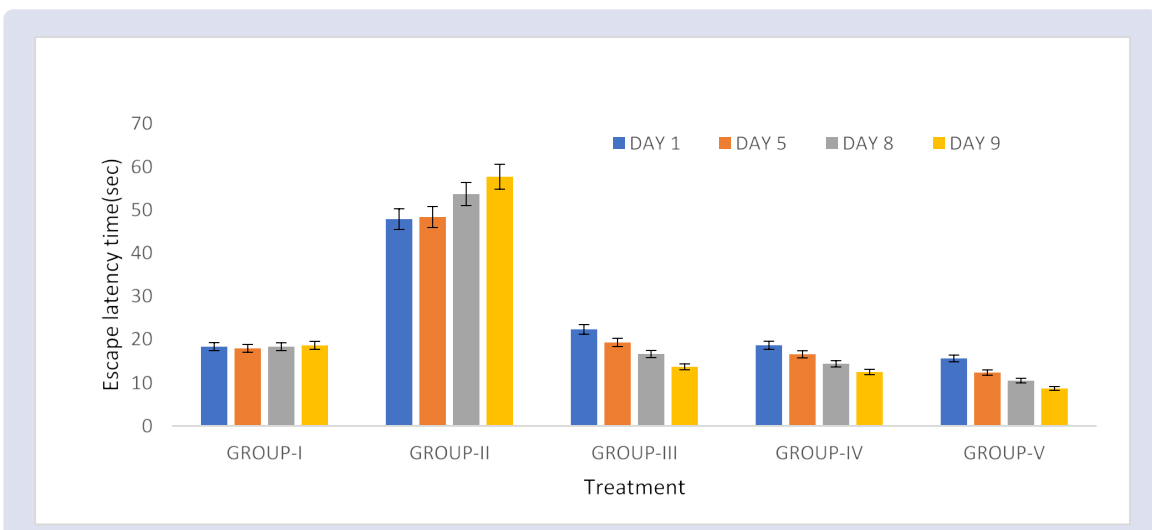

Figure 3: Effect of EESO on elevated plus maze test.

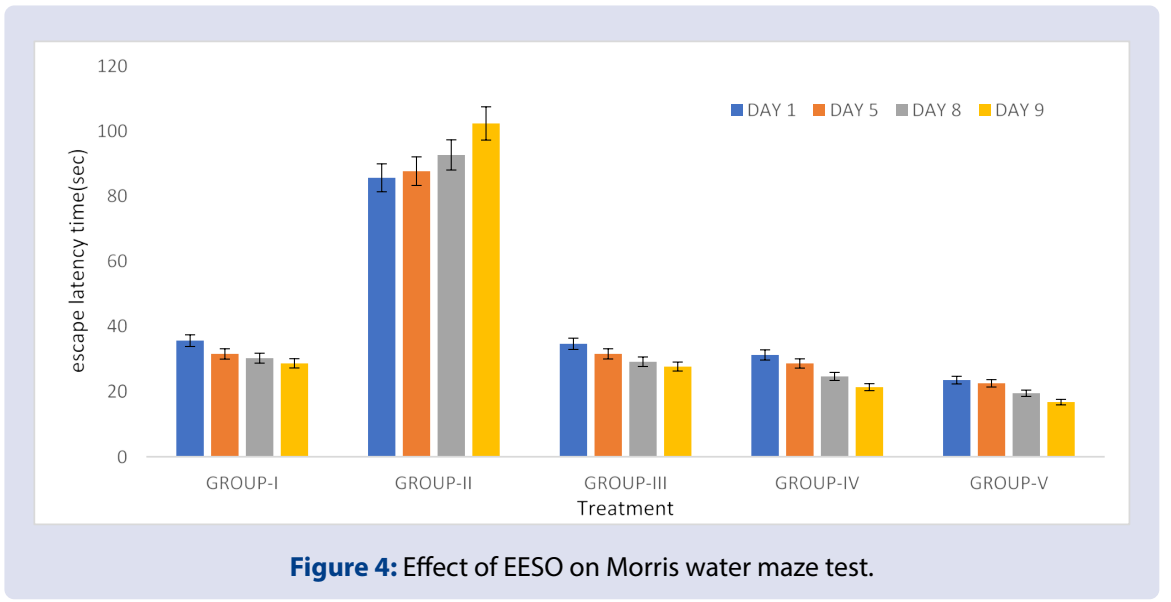




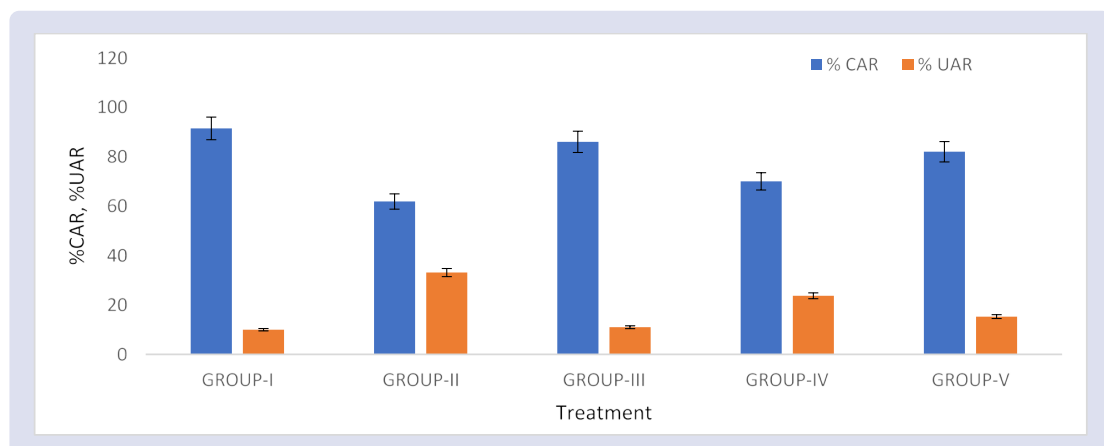

Figure 5: Effect of EESO on the active avoidance learning in scopolamine-induced demented mice.

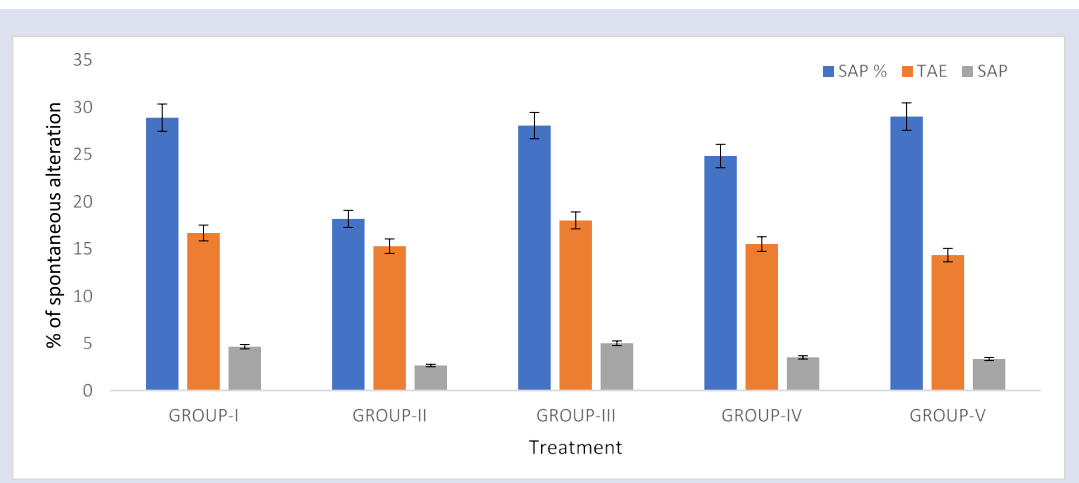

Figure 6: Effect of EESO on Y-maze behavioral test in scopolamine-induced demented mice.

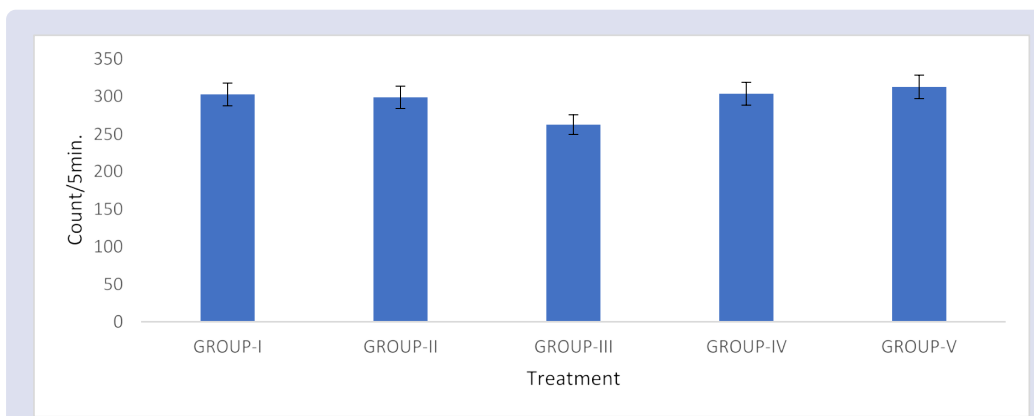

Figure 7: Measurement of locomotor activity.

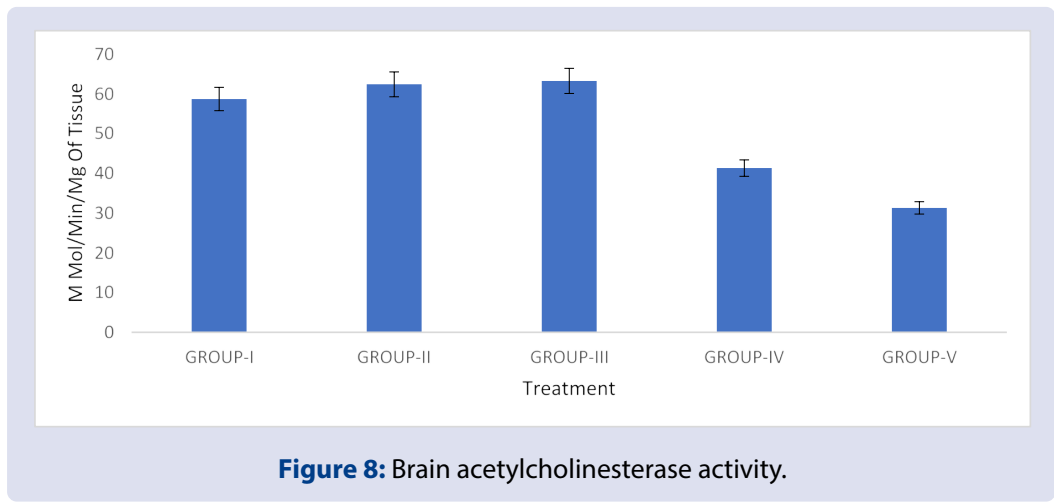




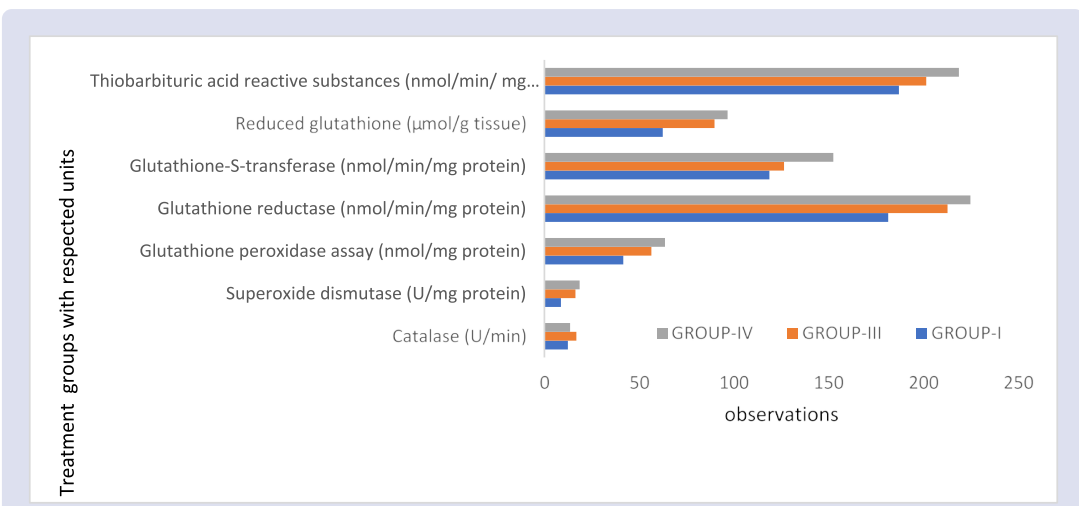

Figure 9: Effect of EESO administration for 7 days in biochemical parameters of animal brain antioxidant status.

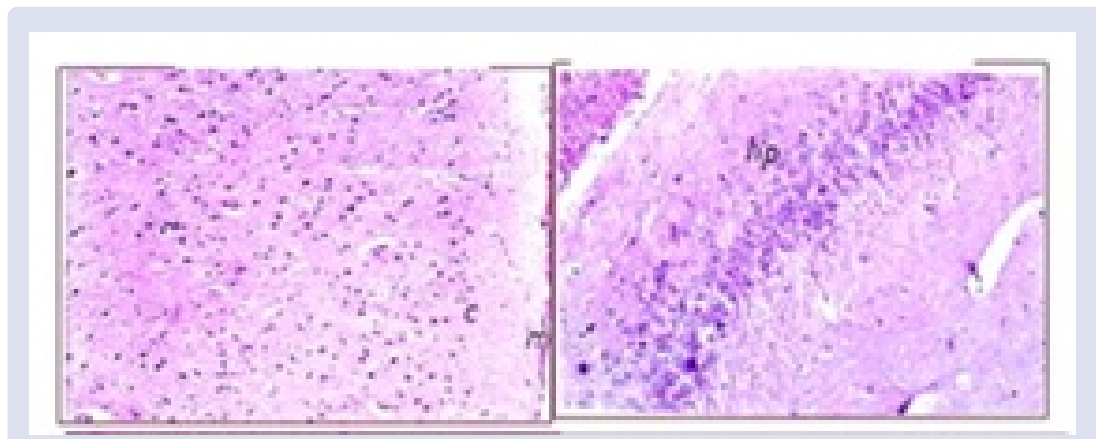

Figure 10: Photomicrograph of brain sections of: (A) control mice showing the normal histological structure of the meninges ( $\mathrm{m})$, cerebral cortex (c) and hippocampus (hp).

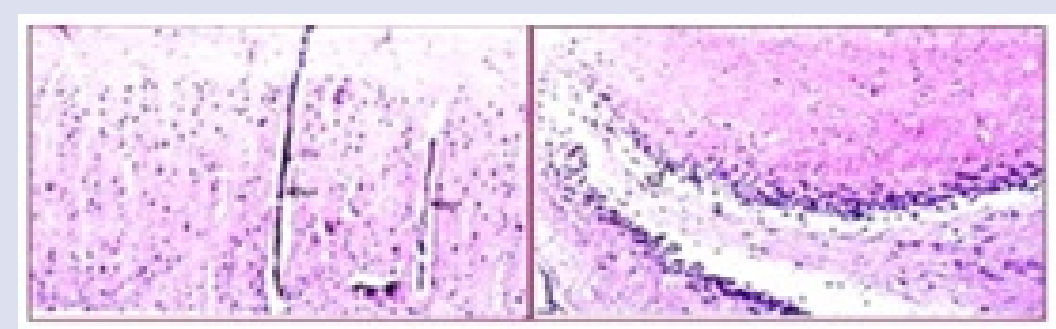

Figure 11: Photomicrograph of brain sections of:(B) scopolamine induced demented mice showing severe congestion in the blood capillaries with perivascular edema (arrow) in the cerebral cortex together with edema and encephalomalacia in the hippocampus (d).

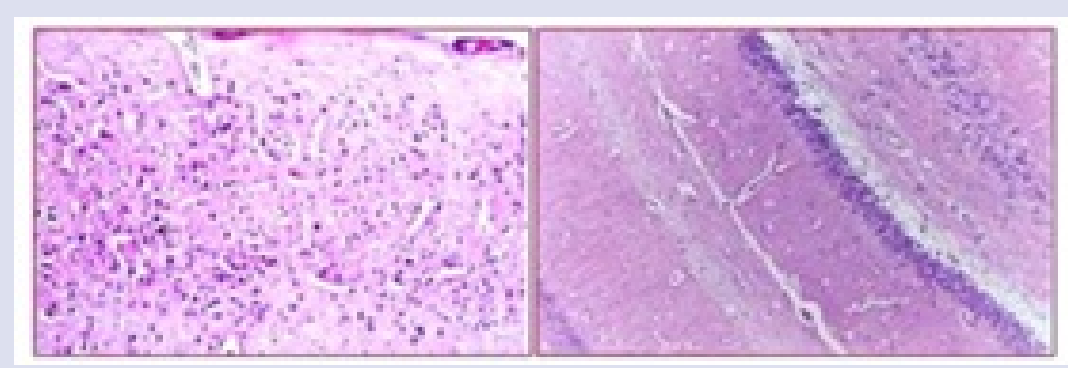

Figure 12: Photomicrograph of brain sections of:(C) Scopolamine induced demented mice treated with piracetam showing diffuse gliosis in the cerebral cortex and shrinkage with pyknotic nuclei in some pyramidal cells in the hippocampus. 

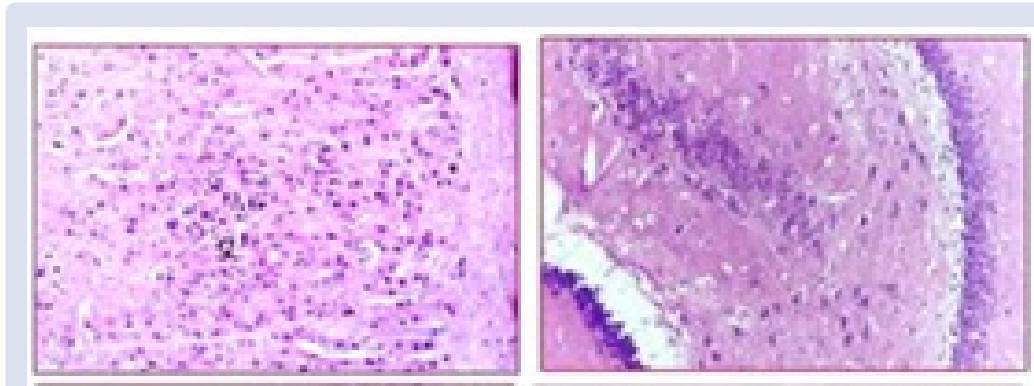

Figure 13: Photomicrograph of brain sections of:(D) scopolamine-induced demented mice treated with EESO $(200 \mathrm{mg} / \mathrm{kg})$ showing focal gliosis $(\mathrm{g})$ in the cerebral cortex and pyramidal cells in the hippocampus separated away from each other with irregular outline.

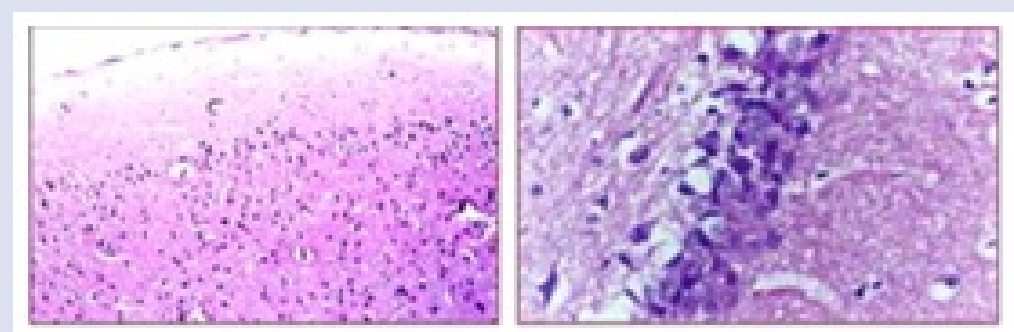

Figure 14: Photomicrograph of brain sections of: (E) scopolamine-induced demented mice treated with EESO $(400 \mathrm{mg} / \mathrm{kg})$ showing the normal histologic structure of the cerebral cortex in addition to shrinkage with pyknotic nuclei in some pyramidal cells and vacuolated cytoplasm in the hippocampus.

\section{Procedure}

- $500 \mathrm{gms}$ of plant powder to be extracted is taken into the feed chamber.

- Then $2000 \mathrm{ml}$ of solvent is taken in to the solvent feed chamber.

- When the motor is turned on for mixing the solvent gets mixed with the plant powder.

- The solvent continuously flows through the plant powder chamber and gets collected at the opposite end of the solvent feed.

- The collected solvent is again introduced into the solvent feed chamber after filtering for the extract.

- This process is repeated for 12 hours.

- Finally when the powder in the chamber gets reduced to $50 \%$ the process is stopped.

- And again repeated the same process with the collected extract with fresh solvent of $1000 \mathrm{ml}$. and the filtrate from this second step is taken for drying using rota evaporator.

\section{Acute toxicity study}

Acute toxicity study was carried using mice by up and down/staircase method as per OECD guidelines. The aim of this experiment was to determine the LD50 of the crude extract. Mice were randomly divided into five groups of 2 animals each. Group-1 served as control and received normal saline $(10 \mathrm{ml} / \mathrm{kg}$ ) while other groups (Group 2, 3, 4 and 5) were given different doses of crude extract in an ascending order that is, $100,500,1000,15002000 \mathrm{mg} / \mathrm{kg}$ respectively. The mortality rate observed for $24 \mathrm{~h}$. Since no mortality occurred, another five groups of mice were taken. All the doses administered by intra-peritoneal route. The highest dose that did not kill any animals and the lowest dose that resulted in mortality were noted. LD50 was calculated from the geometric mean of these two doses.

\section{Disease induction and experimental design}

Animals were classified into five groups (6 mice each). Treatments were given p.o. for 27 successive days. After the last dose of test agents on $17^{\text {th }}$ day, all animals were i.p. injected with scopolamine hydro bromide (20 $\mathrm{mg} / \mathrm{kg}$ ) except the first group (control group). Animals were treated according to the selected doses of extracts in respected groups. ${ }^{17}$

\section{Study design for activity}

Experimental animals: Swiss albino Mice (20-25g)

Animals were grouped randomly into 5 groups, five Mice each.

Group1: Vehicle control group - Mice treated with distilled water.

Group 2: control group - Mice were treated with scopolamine hydrobromide $(20 \mathrm{mg} / \mathrm{kg})$ i.p. injectionon the initial day of experiment.

Group 3: Mice were treated with scopolamine hydrobromide $(20 \mathrm{mg} /$ $\mathrm{kg}$ ) i.p., on the initial day of experiment along with the administration of Low dose of EESO $200 \mathrm{mg} / \mathrm{kg}$

Group 4:Mice were treated with scopolamine hydrobromide $(20 \mathrm{mg} /$ $\mathrm{kg}$ ) i.p., on the initial day of experiment along with the administration of high dose of EESO $400 \mathrm{mg} / \mathrm{kg}$

Group 5: Standard control group -Mice were treated with scopolamine hydrobromide $(20 \mathrm{mg} / \mathrm{kg})$ i.p., along with the administration of Piracetam for 10 days.

The animals were administered with doses for seven days and parameters were evaluated. ${ }^{18}$ 
Table 1: Preliminary phytochemical screening.

\begin{tabular}{cc}
\hline Phytochemical & Salvia.officinalis \\
\hline Steroid & - \\
Alkaloid & - \\
Tannin & + \\
Carbohydrate & + \\
Phenol & + \\
Flavonoids & - \\
Saponin & + \\
Reducing sugar & + \\
Protein & - \\
Amino acid(free) & + \\
Terpenoids & + \\
Coumarin & +
\end{tabular}

(+) Present. (-) Absent

Table 2: Quantitative analysis of phytochemical constituents.

\begin{tabular}{|c|c|c|c|c|c|}
\hline Type of extract & $\begin{array}{c}\text { Total phenolics } \\
\text { (mg GAE/100 g DW) }\end{array}$ & $\begin{array}{c}\text { Total flavonoids } \\
\text { (mg GAE/100 g DW) }\end{array}$ & $\begin{array}{c}\text { Total saponins } \\
\text { (mg GAE/100 g DW) }\end{array}$ & $\begin{array}{c}\text { Total alkaloids (mg } \\
\text { GAE/100 g DW) }\end{array}$ & $\begin{array}{c}\text { Essential oils } \\
(\mu \mathrm{g} / \mathrm{ml})\end{array}$ \\
\hline EESO & 31.15 & 18.46 & - & - & 62.65 \\
\hline MESO & 21.34 & 12.54 & - & - & 53.45 \\
\hline HASO & 22.51 & 12.34 & - & - & 55.62 \\
\hline
\end{tabular}

(Milligrams of gallic acid equivalent per gram of dry weight (mg GAE/g dw))

Note: depending upon the quantity of the chemical constituents present, only ethanolic extracts are preferred for the further studies.

Table 3: Determination of percentage Yield of major compounds using HPTLC densitogram.

\begin{tabular}{|c|c|c|c|c|c|c|c|}
\hline S. No. & Extracts & $\begin{array}{c}\text { Yield } \\
(\% \mathrm{w} / \mathrm{v})\end{array}$ & $\begin{array}{l}\text { Total number } \\
\text { of spots }\end{array}$ & $\begin{array}{l}\text { Number of } \\
\text { major spots }\end{array}$ & $\begin{array}{l}\text { Retention factor } \\
\text { (Rf) }\end{array}$ & $\begin{array}{l}\% \text { Area (with } \\
\text { reference to } \\
\text { crude extract) }\end{array}$ & $\begin{array}{l}\% \text { Yield* of major } \\
\text { compound }\end{array}$ \\
\hline \multirow{3}{*}{1.} & \multirow{3}{*}{ MESO } & \multirow{3}{*}{13.0} & \multirow{3}{*}{8} & \multirow{3}{*}{3} & 0.28 & 16.22 & 0.51 \\
\hline & & & & & 0.42 & 32.40 & 1.04 \\
\hline & & & & & 0.52 & 37.73 & 1.21 \\
\hline
\end{tabular}

Table 4: Effect of EESO on elevated plus maze test.

\begin{tabular}{ccccc}
\hline \multirow{2}{*}{ TREATMENT } & \multicolumn{4}{c}{ Escape Latency Time (In Second) (Mean \pm SEM) } \\
\cline { 2 - 5 } & DAY 1 & DAY 5 & DAY 8 & $18.34 \pm 1.05$ \\
GROUP-I & $18.35 \pm 1.25$ & $17.95 \pm 1.02$ & $53.67 \pm 1.85$ & $57.68 \pm 1.09$ \\
GROUP-II & $47.86 \pm 1.35$ & $48.35 \pm 1.06$ & $16.64 \pm 1.04$ & $13.67 \pm 1.08$ \\
GROUP-III & $22.34 \pm 1.52$ & $19.32 \pm 1.28$ & $14.37 \pm 1.05$ & $12.48 \pm 1.24$ \\
GROUP-IV & $18.65 \pm 134$ & $16.58 \pm 1.35$ & $10.48 \pm 1.04$ & $8.67 \pm 1.04$ \\
GROUP-V & $15.62 \pm 1.52$ & $12.35 \pm 1.31$ & & \\
\hline
\end{tabular}

$\mathrm{N}=6$, Mean \pm SEM.

Table 5: Effect of EESO on Morris water maze test.

\begin{tabular}{ccccc}
\hline \multirow{2}{*}{ TREATMENT } & \multicolumn{4}{c}{ Escape Latency Time (In Second) (Mean \pm SEM) } \\
\cline { 2 - 5 } & DAY 1 & DAY 5 & DAY 8 & DAY 9 \\
\hline GROUP-I & $35.65 \pm 1.39$ & $31.56 \pm 1.25$ & $30.27 \pm 1.35$ & $102.34 \pm 1.34$ \\
GROUP-II & $85.64 \pm 1.54$ & $87.68 \pm 1.24$ & $92.67 \pm 1.48$ & $27.67 \pm 1.34$ \\
GROUP-III & $34.67 \pm 1.24$ & $31.58 \pm 1.65$ & $29.16 \pm 1.26$ & $21.37 \pm 1.38$ \\
GROUP-IV & $31.24 \pm 1.06$ & $28.64 \pm 1.24$ & $24.67 \pm 1.24$ & $16.78 \pm 1.81$ \\
GROUP-V & $23.54 \pm 1.08$ & $22.54 \pm 1.58$ & $19.49 \pm 1.57$ & \\
\hline
\end{tabular}

$\mathrm{N}=6$, Mean \pm SEM.

Table 6: Effect of EESO on the active avoidance learning in scopolamine-induced demented mice.

\begin{tabular}{ccc}
\hline & \multicolumn{2}{c}{ Parameters } \\
\cline { 2 - 3 } TREATMENT & \% CAR & \% UAR \\
\hline GROUP-I & $91.43 \pm 2.10$ & $10.00 \pm 1.83$ \\
GROUP-II & $61.88 \pm 3.65$ & $33.13 \pm 2.49$ \\
GROUP-III & $70.00 \pm 3.54$ & $11.00 \pm 2.45$ \\
GROUP-IV & $86.00 \pm 3.67$ & $23.75 \pm 4.73$ \\
GROUP-V & $82.00 \pm 4.64$ & $15.30 \pm 3.28$ \\
\hline
\end{tabular}


Table 7: Effect of EESO on Y-maze behavioral test in scopolamine-induced demented mice.

\begin{tabular}{cccc}
\hline \multirow{2}{*}{ TREATMENT } & \multicolumn{3}{c}{ Parameters } \\
\cline { 2 - 4 } & SAP $\%$ & TAE & SAP \\
\hline GROUP-I & $28.88 \pm 0.66$ & $16.67 \pm 2.30$ & $4.63 \pm 0.68$ \\
GROUP-II & $18.16 \pm 1.45$ & $15.27 \pm 1.66$ & $2.64 \pm 0.51$ \\
GROUP-III & $24.82 \pm 1.61$ & $15.50 \pm 5.25$ & $3.50 \pm 1.61$ \\
GROUP-IV & $28.04 \pm 1.78$ & $18.00 \pm 4.97$ & $4.00 \pm 0.71$ \\
GROUP-V & $29.00 \pm 1.56$ & $14.33 \pm 1.54$ & $3.33 \pm 0.42$ \\
\hline
\end{tabular}

$\mathrm{N}=6$, Mean $\pm \mathrm{SEM}$.

Table 8: Effect of EESO on locomotor activity.

\begin{tabular}{ccc}
\hline S.NO & TREATMENT & Locomotor activity counts/5 min \\
\hline 1 & GROUP-I & $302.5 \pm 1.26$ \\
2 & GROUP-II & $238.65 \pm 1.34$ \\
3 & GROUP-III & $262.34 \pm 1.29$ \\
4 & GROUP-IV & $303.48 \pm 1.48$ \\
5 & GROUP-V & $312.54 \pm 1.43$ \\
\hline
\end{tabular}

$\mathrm{N}=6$, Mean $\pm \mathrm{SEM}$

Table 9: Effect of EESO on Brain acetylcholinesterase.

\begin{tabular}{ccc}
\hline S.NO & TREATMENT & Acetylcholinesterase Activity (M Mol/Min/Mg of Tissue) \\
\hline 1 & GROUP-I & $58.67 \pm 1.95$ \\
2 & GROUP-II & $62.37 \pm 1.27$ \\
3 & GROUP-III & $63.22 \pm 1.85$ \\
4 & GROUP-IV & $41.31 \pm 1.58$ \\
5 & GROUP-V & $31.29 \pm 1.25$ \\
\hline
\end{tabular}

$\mathrm{N}=6$, Mean $\pm \mathrm{SEM}$

Table 10: Effect of EESO administration for 7 days in biochemical parameters of animal brain antioxidant status.

\begin{tabular}{|c|c|c|c|c|c|c|c|}
\hline Treatment & Catalase (U/min) & $\begin{array}{l}\text { Superoxide } \\
\text { dismutase (U/ } \\
\text { mg protein) }\end{array}$ & $\begin{array}{c}\text { Glutathione } \\
\text { peroxidase } \\
\text { assay (nmol/mg } \\
\text { protein) }\end{array}$ & $\begin{array}{c}\text { Glutathione } \\
\text { reductase } \\
\text { (nmol/min/mg } \\
\text { protein) }\end{array}$ & $\begin{array}{c}\text { Glutathione- } \\
\text { S-transferase } \\
\text { (nmol/min/mg } \\
\text { protein) }\end{array}$ & $\begin{array}{c}\text { Reduced } \\
\text { glutathione } \\
\text { ( } \mu \mathrm{mol} / \mathrm{g} \text { tissue })\end{array}$ & $\begin{array}{c}\text { Thiobarbituric acid } \\
\text { reactive substances } \\
\text { (nmol/min/ } \mathrm{mg} \\
\text { protein) }\end{array}$ \\
\hline GROUP-I & $12.35 \pm 1.42$ & $8.67 \pm 1.75$ & $41.59 \pm 1.27$ & $181.34 \pm 1.6$ & $118.67 \pm 1.07$ & $62.37 \pm 1.08$ & $186.95 \pm 1.05$ \\
\hline GROUP-III & $16.84 \pm 1.04$ & $16.37 \pm 1.48$ & $56.37 \pm 1.58$ & $212.64 \pm 2.0$ & $126.37 \pm 1.07$ & $89.67 \pm 1.05$ & $201.37 \pm 1.5$ \\
\hline GROUP-IV & $13.54 \pm 1.06$ & $18.54 \pm 1.54$ & $63.57 \pm 1.4$ & $224.68 \pm 2.1$ & $152.37 \pm 1.08$ & $96.58 \pm 1.06$ & $218.63 \pm 1.2$ \\
\hline
\end{tabular}

$\mathrm{N}=6$, Mean $\pm \mathrm{SEM}$

\section{Models for memory enhancement in rats}

\section{Conditioned avoidance test}

The test was carried out using a shuttle box (Reflex-16, Columbus Instruments, USA) as described by Wadenberg ML et al. The shuttle box consisted of two grid floor compartments $(29 \times 29 \times 26 \mathrm{~cm})$ separated by a non-transparent partition with a single opening $(8 \times$ $4.5 \mathrm{~cm})$. Light $(12 \mathrm{~W})$ attached to the ceiling of the shuttle box was used as conditioned stimuli; whereas, the unconditioned stimulus was a foot shock $(0.8 \mathrm{~mA})$ delivered through the metallic grid floor. mice were trained for three days prior to conduction of the experiment by subjecting them to the conditioned stimulus (light) followed by the unconditioned one (electric shock). After injection of scopolamine, each mice was placed in the shuttle box and allowed to adapt for $3 \mathrm{~min}$. Following adaptation, the conditioned stimulus was presented for $10 \mathrm{~s}$ prior to the unconditioned stimulus. If the mice crossed to the opposite compartment during $10 \mathrm{~s}$ of conditioned stimulus, the electric shock was avoided; otherwise failure of avoidance was recorded ${ }^{18}$

\section{Y-maze spontaneous alternation test}

The Y-maze test was performed as described by Wall and Messier. The maze was made of 3 identical arms, $40 \mathrm{~cm}$ long, $35 \mathrm{~cm}$ high and $12 \mathrm{~cm}$ wide, positioned at equal angles and labeled $\mathrm{A}, \mathrm{B}$, and $\mathrm{C}$. mice were placed at the end of one arm and allowed to move freely through the maze during a 5 min session. Spontaneous alternation was examined by visually recording the pattern of entrance into each arm in the maze for each mice. Arm entry was considered to be complete when the hind paws of the mice were completely placed in the arm. Alternation was defined as successive entries into the three arms on overlapping triplet set (i.e., $\mathrm{ABC}, \mathrm{BCA}$.....). Accordingly, the spontaneous alternation performance (SAP) score, spontaneous alternation percentage (SAP $\%)$ and total arm entries (TAE) were calculated. ${ }^{19}$

\section{Elevated plus maze}

The procedure, technique, and end point for testing learning and memory were followed as per the parameters described earlier. The elevated plus maze for mice consisted of two open arms $(16 \mathrm{~cm} \times 5 \mathrm{~cm})$ and two covered arms $(16 \mathrm{~cm} \times 5 \mathrm{~cm} \times 15 \mathrm{~cm})$ extended from a central platform $(5 \mathrm{~cm} \times 5 \mathrm{~cm})$ and the maze was elevated to a height of $25 \mathrm{~cm}$ from the floor. On the first day, each mouse was placed at the end of an open arm, facing away from the central platform. Transfer latency (TL) was defined as the time taken by the animal to move from the open arm into one of the covered arms with all its four legs. TL was recorded on the first day (i.e., 10th day of drug administration) for each animal. If the animal did not enter into one of the covered arm within $90 \mathrm{sec}$, it was gently pushed into one of the two covered arms and TL 
was assigned as $90 \mathrm{sec}$. The mouse was allowed to explore the maze for another 2 minutes and then returned to its home cage. Retention of this learned-task (memory) was examined $24 \mathrm{~h}$ (11th day) after the first day trial. ${ }^{20}$

\section{Morris water maze}

The procedure, technique, and end point for testing memory were followed as per the parameters described earlier. Briefly, Morris water maze-(MWM) for mice consisted of a circular pool $(60 \mathrm{~cm}$ in diameter, $25 \mathrm{~cm}$ in height) filled to a depth of $20 \mathrm{~cm}$ with water maintained at $25^{\circ} \mathrm{C}$. The water was made opaque with nontoxic white colored dye. The tank was divided into four equal quadrants with the help of two threads, fixed at right angle to each other on the rim of the pool. A submerged platform (with top surface $6 \mathrm{~cm} \times 6 \mathrm{~cm}$ and painted in white) was placed inside the target quadrants (Q4 in present study) of this pool $1 \mathrm{~cm}$ below surface of water. The position of platform was kept unaltered throughout the training session. Each animal was subjected to four consecutive trials each day with a gap of $5 \mathrm{~min}$ for four consecutive days (starting from 6th day of drug administration to 9th day), during which they were allowed to escape on to the hidden platform and to remain there for $20 \mathrm{~s}$. During the training session, the mouse was gently placed in the water between quadrants, facing the wall of pool with drop location changing for each trial, and allowed $120 \mathrm{sec}$ to locate submerged platform. If the mouse failed to find the platform within $120 \mathrm{~s}$, it was guided gently on to the platform and allowed to remain there for $20 \mathrm{~s}$. Escape latency (EL) is the time taken by the animal to move from the starting quadrant to find the hidden platform in the target quadrant. EL was recorded on the 6th day to 9th day for each animal. Each animal was subjected to training trials for four consecutive days, the starting position was changed with each exposure as mentioned below and target quadrant $(\mathrm{Q} 4$ in the present study) remained constant throughout the training period.

- Day1 Q1 Q2 Q3 Q4.

- $\quad$ Day2 Q2 Q3 Q4 Q1.

- Day3 Q3 Q4 Q1 Q2.

- Day4 Q4 Q1 Q2 Q3.

On the fifth day (i.e., 10th day of drug administration), the platform was removed and mouse was placed in any of the three quadrants and allowed to explore the target quadrant for $300 \mathrm{~s}$. Mean time spent in all the three quadrants that is, Q1, Q2, and Q3 was recorded. The mean time spent in the target quadrant in search of the missing platform was noted as index of retrieval or memory. The observer always stood at the same position. Care was taken not to disturb the relative location of water maze with respect to other objects in the laboratory. ${ }^{20}$

\section{Measurement of locomotor activity}

To rule out the effects of the drugs on motor activity, horizontal locomotor activities of control and test animals were recorded for a period of 5 min using Medicraft Photoactometer, Model number 600$4 \mathrm{D}$ (INCO, Ambala, India). The photoactometer consisted of a square arena $(30 \times 30 \times 25 \mathrm{~cm})$ with wire mesh bottom, in which the animal moves. Six lights and six photocells placed in the outer periphery of the bottom in such a way that a single mouse can block only one beam. Technically its principle is that a photocell is activated when animals crossing the beam of light cut off the rays of light falling on the photocells. As the photocell is activated, a count is recorded. The photocells are connected to an electronic automatic counting device which counts the number of "cut offs."

\section{Estimation of brain reduced glutathione content}

The method for the assessment of GSH (mg/g wet tissue) in the brain homogenates was based on that of Beutler et al. Homogenates were de-proteinized with 5-sulfuosalicylic acid (10\%) for $30 \mathrm{~min}$ at $4{ }^{\circ} \mathrm{C}$ then centrifuged at $3000 \mathrm{rpm}$ for $15 \mathrm{~min}$ at $4^{\circ} \mathrm{C}$. An aliquot of the acid soluble supernatant was diluted with phosphate buffer $(0.3 \mathrm{M}, \mathrm{pH}=7.7)$ and $5,5^{\prime}$-dithiobis-2-nitrobenzoic acid $(1 \mathrm{mM})$ was added to the samples. The optical density of the produced colored product was determined at $412 \mathrm{~nm}^{21}$

\section{Biochemical estimation}

\section{Collection of brain sample}

Immediately after behavioural testing (retrieval) on elevated plus maze, animals sacrificed by cervical dislocation under light anaesthesia with diethylether. The whole brain carefully removed from the skull. For preparation of brain homogenate, the fresh whole brain weighed and transferred to a glass homogenizer and homogenized in an ice bath after adding 10 volumes of phosphate buffer $(\mathrm{pH} 8,0.1 \mathrm{M})$. The homogenate was centrifuged using refrigerated centrifuge at $3000 \mathrm{rpm}$ for $10 \mathrm{~min}$ at $4^{\circ} \mathrm{C}$ and the resultant cloudy supernatant liquid used for the estimation of brain acetylcholinesterase activity. ${ }^{21}$

\section{Brain Acetylcholinesterase Activity ${ }^{22}$}

Brain acetylcholinesterase estimated using the method of D.H. den Blaauwen et al. Briefly, $0.4 \mathrm{~mL}$ of brain homogenate was added to a test tube containing $2.6 \mathrm{~mL}$ of phosphate buffer. $0.1 \mathrm{~mL}$ DTNB reagent added to the above mixture and absorbance was noted at $412 \mathrm{~nm}$. $0.02 \mathrm{~mL}$ of acetylcholine iodide solution added and again absorbance was noted $15 \mathrm{~min}$ thereafter. Change in absorbance per min was calculated.

The rate of hydrolysis of substrate was calculated using following formula:

- $R=$ change in absorbance/min $f_{0} \times 5.74 \times 10^{-4} / C 0$,

- $R=$ rate of hydrolysis of acetylcholine iodide $/ \mathrm{min} / \mathrm{mg}$ tissue,

- $C 0=$ weight of tissue homogenate in $\mathrm{mg} / \mathrm{mL}$.

\section{Superoxide dismutase assay (SOD) 22}

SOD activity was estimated by the method of D.H. den Blaauwen et al. Reaction mixture of this method contained: $0.1 \mathrm{ml}$ of phenazine methosulphate $(186 \mu \mathrm{mol}), 1.2 \mathrm{ml}$ of sodium pyrophosphate buffer (0.052 mmol; pH 7.0), $0.3 \mathrm{ml}$ of the supernatant after centrifugation $(1500 \times \mathrm{g}$ for $10 \mathrm{~min}$ followed by $10,000 \times \mathrm{g}$ for $15 \mathrm{~min})$ of homogenate was added to the reaction mixture. Enzyme reaction was initiated by adding $0.2 \mathrm{ml}$ of NADH $(780 \mu \mathrm{mol})$ and stopped after $1 \mathrm{~min}$ by adding $1 \mathrm{ml}$ of glacial acetic acid. Amount of chromogen formed measured by recording color intensity at $560 \mathrm{~nm}$. Results are expressed in units/mg protein.

\section{Estimation of a lipid peroxidation assay $\left(\right.$ TBARS) ${ }^{23}$}

The assay for lipid peroxidation was carried out following the modified method of M. Mihara et al,. The reaction mixture in a total volume of $1.0 \mathrm{ml}$ contained $0.58 \mathrm{ml}$ phosphate buffer ( $0.1 \mathrm{~mol}$; $\mathrm{pH} 7.4), 0.2$ $\mathrm{ml}$ homogenate sample, $0.2 \mathrm{ml}$ ascorbic acid $(100 \mathrm{mmol})$, and 0.02 $\mathrm{ml}$ ferric chloride (100 mmol). The reaction mixture was incubated at $37^{\circ} \mathrm{C}$ in a shaking water bath for $1 \mathrm{~h}$. The reaction stopped by addition of $1.0 \mathrm{ml} \mathrm{10 \%} \mathrm{trichloroacetic} \mathrm{acid.} \mathrm{Following} \mathrm{addition} \mathrm{of} 1.0 \mathrm{ml} 0.67 \%$ thiobarbituric acid, all the tubes were placed in boiling-water bath for $20 \mathrm{~min}$ and then shifted to crushed ice-bath before centrifuging at $2500 \times \mathrm{g}$ for $10 \mathrm{~min}$. The amount of TBARS formed in each of the 
samples assessed by measuring optical density of the supernatant at $535 \mathrm{~nm}$ using a spectrophotometer against a reagent blank. The results expressed as nmol TBARS $/ \mathrm{min} / \mathrm{mg}$ tissue at $37^{\circ} \mathrm{C}$ using a molar extinction coefficient of $1.56 \times 105 \mathrm{M}-1 \mathrm{~cm}-1$.

\section{Glutathione peroxidase assay (GSH-Px) ${ }^{24}$}

Glutathione peroxidase activity assayed by the method of Mohandas et al. The reaction mixture consisted of $1.49 \mathrm{ml}$ phosphate buffer $(0.1$ mol; pH 7.4), $0.1 \mathrm{ml}$ EDTA ( $1 \mathrm{mmol}), 0.1 \mathrm{ml}$ sodium azide $(1 \mathrm{mmol})$, $0.05 \mathrm{ml}$ glutathione reductase $(1 \mathrm{IU} / \mathrm{ml}), 0.05 \mathrm{ml} \mathrm{GSH}(1 \mathrm{mmol}), 0.1$ $\mathrm{ml} \mathrm{NADPH}(0.2 \mathrm{mmol}), 0.01 \mathrm{ml} \mathrm{H} 2 \mathrm{O} 2(0.25 \mathrm{mmol})$ and $0.1 \mathrm{ml}$ of homogenate in a total volume of $2 \mathrm{ml}$. The disappearance of NADPH at $340 \mathrm{~nm}$ recorded at $25^{\circ} \mathrm{C}$. Enzyme activity calculated as nmol $\mathrm{NADPH}$ oxidized $/ \mathrm{min} / \mathrm{mg}$ protein using a molar extinction coefficient of $6.22 \times 103 \mathrm{M}-1 \mathrm{~cm}-1$.

\section{Histopathologic examination of brain tissues}

Histopathologic assessment performed on the brains of 2-3 mice randomly selected from each group. Brains were immediately fixed in $10 \%$ phosphate buffered formaldehyde, embedded in paraffin, and 5 $\mu \mathrm{m}$ longitudinal sections were performed. The sections were stained with hematoxylin and eosin (H\&E) and examined microscopically $(250-350 x){ }^{25}$

\section{Statistical analysis}

Results expressed as Mean \pm S.D. All the results compared with control subject tone-way analysis of variance (ANOVA), followed by the dunnet test using Graph Pad Prism Software 6 version.

P Values $<0.05$ were as considered statistically significant.

\section{RESULTS}

$\%$ yield value of ethanol extract from Aerial Parts of Salvia officinalis plant

Percentage yield of ethanol extract found to be $20 \%$.

\section{Preliminary photochemical screening}

Investigation revealed the presence of Tannin, Carbohydrate, Phenol, Flavonoid, Reducing sugar, protein, Terpenoids and Coumarin.

\section{TLC studies}

The selected extracts subjected to TLC studies and the results were as shown below.

\section{ISOLATION AND CHARACTERIZATION OF COM- POUNDS}

Ethanol extract of Salvia officinalis further subjected to column fractionation using normal phase silica gel column. Those column fractions further purified by Preparative TLC, using Silica gel-G as a stationary phase. From the ethanol extract two major compounds were isolated and identified as rosmarinic acid and carnosic acid. The identification was done using marker compound and NMR spectrum. Another third compound is carnosol.

\section{REPORT FOR ACCUTE TOXICITY STUDIES}

\section{LD50 values of different fractions of Salvia officinalis of E-Ethanolic extract}

$2000 \mathrm{mg} / \mathrm{kg}$ is considered as the lethal dose of the test compound as the animals showed severe side effects. The required amount from the $2000 \mathrm{mg} / \mathrm{kg}$ will be calculated $(200 \mathrm{mg} / \mathrm{kg} \& 400 \mathrm{mgkg})$ and will be administered to animals.

\section{Effect of EESO on elevated plus maze test}

\section{Treatment schedule}

Animals were divided in 4 groups; in each group 6 animals were used. Subgroup 01 (vehicle control: Acacia suspension $1 \mathrm{ml} / \mathrm{kg}$ oral), group 02 (Scopolamine $(20 \mathrm{mg} / \mathrm{kg})$ ), group 3 (EESO $200 \mathrm{mg} / \mathrm{kg}$, oral), group 4 (EESO $400 \mathrm{mg} / \mathrm{kg}$, oral), group 5 standard (piracetam $200 \mathrm{mg} / \mathrm{kg}$ intraperitoneal).

\section{Inference}

The treatment showed positive reports (memory response) as the mice of group-IV showed significant response times $(12.48 \pm 1.24)$ compared to the standard drug $(8.67 \pm 1.04)$ still the results of standard are better but as for a herbal extract the obtained timings are good for consideration and improvement and the group-III animals also showed good results. These results show that the extracts are improving the memory functions of the animals.

\section{Effect of EESO on Morris water maze test}

\section{Treatment schedule}

Animals were divided in 4 groups; in each group 6 animals were used. Subgroup 01 (vehicle control: Acacia suspension $1 \mathrm{ml} / \mathrm{kg}$ oral), group 02 (Scopolamine $(20 \mathrm{mg} / \mathrm{kg}$ )), group 3 (EESO $200 \mathrm{mg} / \mathrm{kg}$, oral), group 4 (EESO $400 \mathrm{mg} / \mathrm{kg}$, oral), group 5 standard (piracetam $200 \mathrm{mg} / \mathrm{kg}$ intraperitoneal).

\section{Inference}

In this test the animals kept in a water maze with four parts separated by a small thread where one part has a base for standing other parts are filled with water mice are placed in the water maze and they must find and the part with the base and stand on it for 20s after the training exercises the treatment is given. As shown in the above table Scopolamine treated mice (group-I) were taken as disease control and the obtained results are compared to it the group-IV mice showed $21.37 \pm 1.38 \mathrm{sec}$ of escape time by the $9^{\text {th }}$ day. And the animals of group-III showed $27.67 \pm 1.34 \mathrm{sec}$ of escape time by the $9^{\text {th }}$ day. These results show that the extracts are improving the memory functions of the animals.

\section{Conditioned avoidance test}

The test was carried out using a shuttle box (Reflex-16, Columbus Instruments, USA) as described by Hinrichs et al. The shuttle box consisted of two grid floor compartments $(29 \times 29 \times 26 \mathrm{~cm})$ separated by a non-transparent partition with a single opening $(8 \times 4.5 \mathrm{~cm})$. Light $(12 \mathrm{~W})$ attached to the ceiling of the shuttle box was used as conditioned stimuli; whereas, the unconditioned stimulus was a foot shock $(0.8$ $\mathrm{mA}$ ) delivered through the metallic grid floor. Mice were trained for three days prior to conduction of the experiment by subjecting them to the conditioned stimulus (light) followed by the unconditioned one (electric shock). After injection of scopolamine, each mice was placed in the shuttle box and allowed to adapt for $3 \mathrm{~min}$. Following adaptation, the conditioned stimulus presented for $10 \mathrm{~s}$ prior to the unconditioned stimulus. If the mice crossed to the opposite compartment during 10 $\mathrm{s}$ of conditioned stimulus, the electric shock was avoided; otherwise failure of avoidance was recorded.

\section{Treatment schedule}

Animals were divided in 4 groups; in each group 6 animals were used. Subgroup 01 (vehicle control: Acacia suspension $1 \mathrm{ml} / \mathrm{kg}$ oral), group 02 (Scopolamine $(20 \mathrm{mg} / \mathrm{kg})$ ), group 3 (EESO $200 \mathrm{mg} / \mathrm{kg}$, oral), group 
4 (EESO $400 \mathrm{mg} / \mathrm{kg}$, oral), group 5 standard (piracetam $200 \mathrm{mg} / \mathrm{kg}$ intraperitoneal).

Each value represents the mean percentage of conditioned (CAR) and unconditioned (UAR) avoidances for each group (6mice) \pm S.E.

\section{Inference}

The electric shock escape or conditioned avoidance percentage for GROUP-V is $82.00 \%$ and the GROUP-IV showed promising results with $70.00 \pm 3.54 \%$ which is lower compared to the GROUP-V, but it shows that the extracts given are acting on improving the animal memory and remembering capabilities.

\section{Y-maze spontaneous alternation test}

\section{Treatment schedule}

Animals were divided in 5 groups; in each group 6 animals were used. Subgroup 01 (vehicle control: Acacia suspension $1 \mathrm{ml} / \mathrm{kg}$ oral), group 02 (Scopolamine $(20 \mathrm{mg} / \mathrm{kg})$ ), group 3 (EESO $200 \mathrm{mg} / \mathrm{kg}$, oral), group 4 (EESO $400 \mathrm{mg} / \mathrm{kg}$, oral), group 5 standard (piracetam $200 \mathrm{mg} / \mathrm{kg}$ intraperitoneal).

Piracetam and EESO were orally administered for 7 successive days. Dementia was induced on the 7th day by single i.p. injection of scopolamine $1 \mathrm{~h}$ after the last dose of test agents. Y-maze behavioral test was performed $1 \mathrm{~h}$ after scopolamine injection. Total arm entries (TAE) and spontaneous alternation performance (SAP) were measured during 5-min session and \% SAP was calculated.

Data are expressed as mean \pm S.E.M of 6 animals. Statistical analysis was carried out by non-parametric One-Way ANOVA followed by Dunn's multiple comparisons test.

\section{Inference}

In this test the observation is for mice to enter the Y-maze arms in the given intervals and it was found that the results of group-VI(28.04 \pm $1.78)$ are similar to that of standard drug treated mice group- $\mathrm{V}(29.00$ $\pm 1.56)$.

\section{Measurement of locomotor activity}

Locomotor activity was measured $24 \mathrm{~h}$ after performing water maze test in mice of groups 3 to 5 using photoactometer (INCO, Ambala).

\section{Treatment schedule}

Animals were divided in 5 groups; in each group 6 animals were used. Subgroup 01 (vehicle control: Acacia suspension $1 \mathrm{ml} / \mathrm{kg}$ oral), group 02 (Scopolamine $(20 \mathrm{mg} / \mathrm{kg})$ ), group 3 (EESO $200 \mathrm{mg} / \mathrm{kg}$, oral), group 4 (EESO $400 \mathrm{mg} / \mathrm{kg}$, oral), group 5 standard (piracetam $200 \mathrm{mg} / \mathrm{kg}$ intraperitoneal).

\section{Inference}

In this test Scopolamine induced demented mice observed for their motor activity or movement, the GROUP-VI animals showed results $(303.48 \pm 1.48)$ similar to that of control group $(302.5 \pm 1.26)$ and similar to that of standard group $(312.54 \pm 1.43)$ as there is no big difference in the results.

\section{BRAIN ACETYLCHOLINESTERASE ACTIVITY}

Brain acetylcholinesterase was estimated using the method of Ellman et al. Briefly, $0.4 \mathrm{~mL}$ of brain homogenate was added to a test tube containing $2.6 \mathrm{~mL}$ of phosphate buffer. $0.1 \mathrm{~mL}$ DTNB reagent was added to the above mixture and absorbance was noted at $412 \mathrm{~nm}$. $0.02 \mathrm{~mL}$ of acetylcholine iodide solution was added and again absorbance was noted $15 \mathrm{~min}$ thereafter. Change in absorbance per min was calculated.
The rate of hydrolysis of substrate was calculated using following formula:

$$
\begin{aligned}
& R=\text { change in absorbance } / \mathrm{min} \times 5.74 \times 10^{-4} / \mathrm{C} 0, \\
& R=\text { rate of hydrolysis of acetylcholine iodide } / \mathrm{min} / \mathrm{mg} \text { tissue, } \\
& C 0 \text { = weight of tissue homogenate in } \mathrm{mg} / \mathrm{mL} .
\end{aligned}
$$

\section{Treatment schedule}

Animals were divided in 4 groups; in each group 6 animals were used. Subgroup 01 (vehicle control: Acacia suspension $1 \mathrm{ml} / \mathrm{kg}$ oral), group 02 (Scopolamine $(20 \mathrm{mg} / \mathrm{kg})$ ), group 3 (EESO $200 \mathrm{mg} / \mathrm{kg}$, oral), group 4 (EESO $400 \mathrm{mg} / \mathrm{kg}$, oral), group 5 standard (piracetam $200 \mathrm{mg} / \mathrm{kg}$ intraperitoneal).

\section{Inference}

The higher the concentration of cholinesterase the higher is the rested state the treatment of Scopolamine induced mice with EESO showed decrease $(41.31 \pm 1.58)$ of cholinesterase enzyme.

\section{Effect of EESO administration for 7 days in biochemical parameters of animal brain antioxidant status}

\section{Inference}

Anti oxidants plays a major role in the body immune system. The higher the concentration the higher is the tissue regeneration capabilities the ethanolic extracts of salvia officinalis showed better results as for the concentration of catalase and DPPH activity.

\section{Histopathological evaluation}

\section{Inference}

In the histopathological evaluation the brain tissues were collected and observed for tissue damage and regeneration for this the GROUP-I animal samples were taken as standard and compared to others. Group-II tissues shows the tissue damage over the treatment period, where the group-III showing slow recovery of the tissues whereas the group-IV and GROUP-V showed regenerated cells to fully regenerated cells.

\section{CONCLUSION}

The studies carried out on Ethanolic extract of Salvia officinalis plant at two different doses $(200 \mathrm{mg} / \mathrm{kg}, 400 \mathrm{mg} / \mathrm{kg})$ showed dose dependent activity.

Alzheimer's disease is progressive neurodegenerative disorder which affects older individuals. It is the most common cause of dementia. It is associated with the presence of senile plaques which are deposition of beta- amyloid protein in the hippocampus area of the brain. Herbal medicine offers several options to modify the progress and symptoms of $\mathrm{AD}$. In conclusion the investigation revealed that the Salvia officinalis have significant potential in memory and sensory improving/recovery making it possible to continue the study with possible modifications for betterment of the results, though obtained results may not be higher than the standard marketed formulations, these prepared herbal formulations can be used as a secondary source for the treatment. Further studies can be performed by preparing herbal formulations from the isolated compounds and stabilizing the prepared formulations. India is a country has a rich source of plant life further studies are needed to finding out the medicinal properties of the available plant life.

\section{ACKNOWLEDGEMENTS}

It is my privilege to convey my sincere regards and deep sense of gratitude to my beloved guide -Prof. Shailendra Patil for his keen interest in my project work, generous supervision, inspiring guidance, 
valuable suggestions and free hand at work made the development of this study possible.

\section{DECLARATION OF INTEREST}

All the authors have no conflicts of interest.

\section{REFERENCES}

1. Thippeswamy BS, Mishra B, Veerapur VP, Gupta G. Anxiolytic activity of Nymphaea alba linn. In mice as experimental models of anxiety. Indian J Pharmacol. 2011;43:50-5.

2. Bhat $R$, Sridhar $K R$, Seena $S$. Nutritional quality evaluation of velvet bean seeds (Mucuna pruriens) exposed to gamma irradiation. Int J Food Sci Nutr. 2008;59(4):261-78.

3. Houghton PJ, Osibogun IM. Flowering plants used against snakebite. J Ethnopharmacol. 1993;39(1):1-29.

4. Jalal Z, Phytochemistry of the essential oil of Melissa officinalis L. growing wild in Morocco:Preventive approach against nosocomial infections. Asian Pacific Journal of Tropical Biomedicine. 2015,5(6):458-61.

5. Komes D. Phenolic composition and antioxidant properties of some traditionally used medicinal plants affected by the extraction time and hydrolysis. Phytochem Anal. 2011;22(2):172-80.

6. Gracon SI, Knapp MJ, Berghoff WG. Safety of tacrine: clinical trials, treatment IND, and postmarketing experience. Alzheimer Dis Assoc Disord. 1998;12:93101.

7. Nadkarni S, Devinsky O. Psychotropic effects of antiepileptic drugs. Epilepsy Curr. 2005;5(5):176-81.

8. Xu H, Liu Z, Liu Y. Administration of midazolam in infancy does not affect learning and memory of adult mice. Clin Exp Pharmacol Physiol. 2009;36:11448.

9. Tian J, Shi J, Zhang $X$, Wang Y. Herbal therapy: a new pathway for the treatment of Alzheimer's disease. Alzheimers Res Ther. 2010;2(5):30.

10. Fecka I, Turek S. Determination of water-soluble polyphenolic compounds in commercial herbal teas from Lamiaceae: peppermint, melissa, and sage. J Agric Food Chem. 2007;26;55(26):10908-17.

11. Barros L. Phenolic profiles of cultivated, in vitro cultured and commercial samples of Melissa officinalis L. infusions. Food Chem. 2013;136(1):1-8.

12. Taiwo AE. Anxiolytic and antidepressant-like effects of Melissa officinalis (lemon balm) extract in rats: Influence of administration and gender. Indian J Pharmacol. 2012;44(2):189-92.
13. Wake G. CNS acetylcholine receptor activity in European medicinal plants traditionally used to improve failing memory. J Ethnopharmacol. 2000;69(2):105 14.

14. Kennedy DO. Modulation of mood and cognitive performance following acute administration of single doses of Melissa officinalis (Lemon balm) with human CNS nicotinic and muscarinic receptor-binding properties. Neuropsychopharmacology. 2003;28(10):1871-81.

15. Ziaková A, Brandsteterová E, Blahová E. Matrix solid-phase dispersion for the liquid chromatographic determination of phenolic acids in Melissa officinalis. J Chromatogr A. 2003.

16. Wolbling $\mathrm{RH}$, Leonhardt K. Local therapy of herpes simplex with dried extract from Melissa officinalis. Phytomedicine. 1994;1(1):25-31.

17. Rao RN, Talluri MV, Krishna TS, Ravindranath K. Continuous counter current extraction, isolation and determination of solanesol in Nicotiana tobacum L. by non-aqueous reversed phase high performance liquid chromatography. $J$ Pharm Biomed Anal. 2008;46(2):310-5.

18. Shamnas M. Neuroprotective activity of methanol extract of Salvia officinalis flowers in dementia related to Alzheimer disease Der. Pharmacia Sinica. 2014;5(2):29-38.

19. Wadenberg ML. Conditioned avoidance response in the development of new antipsychotics. Curr Pharm Des. 2010;16(3):358-70

20. P.M. Wall, C. Messier, Infralimbic kappa opioid and muscarinic M1 receptor interactions in the concurrent modulation of anxiety and memory. Psychopharmacology (Berl). 2002;160:233-44.

21. E Beutler, O Duron, BM Kelly. Improved method for the determination of blood glutathione. J Lab Clin Med. 1963;61:882-8.

22. DH den Blaauwen, WA Poppe, W Tritschler. Cholinesterase (EC 3.1.1.8) with butyrylthiocholine-iodide as substrate: References depending on age and sex with special reference to hormonal effects and pregnancy. J Clin Chem Clin Biochem. 1983;21:381-6.

23. Mihara. M, Uchiyama M. Determination of malonaldehyde precursor in tissues by thiobarbituric acid test. Anal Biochem. 1978;86:271-8.

24. Mohandas J, Marshal JJ, Duggin GG, Horvath JS, Tiller DJ. Differentia distribution of glutathione and glutathione-related enzymes in rabbit kidney. Possible implications in analgesic nephropathy. Biochem Pharmacol. 1984;33:1801-7.

25. Hala F Zaki, May A Abd-El-Fattah, Amina S Attia. Naringenin protects against scopolamine-induced dementia in rats, Bulletin of Faculty of Pharmacy, Cairo University. 2014;52:15-25.

\section{GRAPHICAL ABSTRACT}
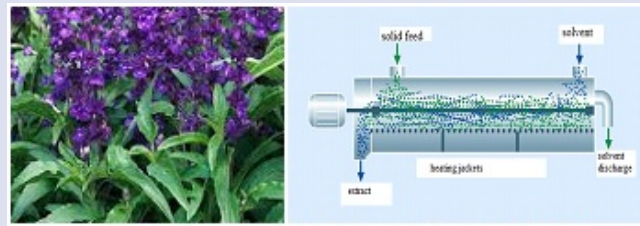

Extraction of Salvia offiainalis by counter current extraction
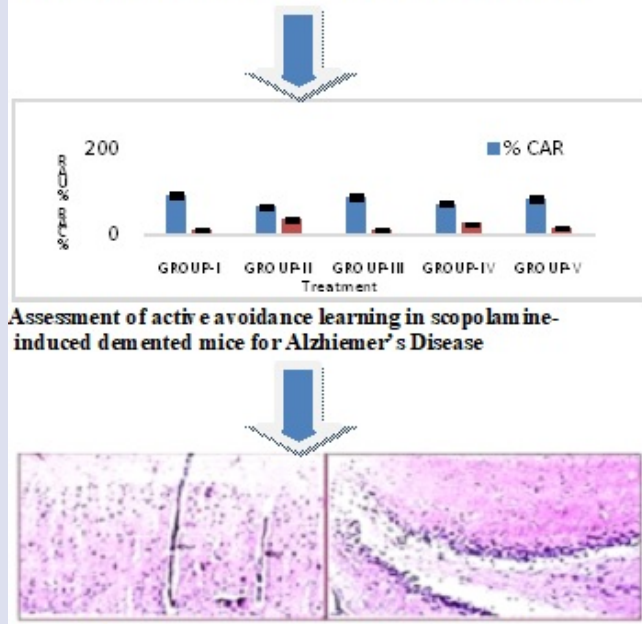

Histopathological evaluation in scopolamine-induced

demented mice 


\section{ABOUT AUTHORS}

Sanjana Datta: Sanjana is B.Pharm, M.Pharm (Pharmacognosy), Pursuing PhD, working as Assistant Professor at Pharmaceutical Technology Department, Meerut Institute of Enigneering Technology, Meerut, and U.P. She has six years of teaching experience in pharmacy field.She has 4 international publications. Her current work emphasizes on the treatment of Alzheimer's diseases using medicinal plants. This research paper is based on the work which is performed.

Dr. Shailendra Patil: Dr. Shailendra Patil is currently working as Professor and Dean, faculty of Pharmacy, Medical Sciences and Paramedical Sciences at Swami Vivekanand University, Sagar MP. He received his doctoral degree in Pharmaceutical Sciences, Dr. Harisingh Gour Vishwavidyalaya, Sagar. He has worked as Assistant Professor, Associate Professor, Professor and Principal at various institutions and has 22years of experience. He has authored 37 publications in various journals of National and International repute. His publication reflects his research interest in novel drug delivery. He has filed a patent and coauthored a book "In vitro Experimental Pharmacology". He is the Chairman of Board of Studies, Institutional Animal Ethics Committee and Director of IQAC. He is the recipient of various awards namely a) Best Academician Award 2019 in Pharma Ratna Award by RBD, New Dehi, b)Best Director/Principal Award - 2019 in SAS International Conference and Award 2019 by SAS Society, Hojai, Assam India, c) Best Director/Principal Award - 2019 in 7th Academic Brilliance Award 2019 by EET CRS, Greater Noida, UP, d)Best Educationist Award - 2017 by International Institute of Education and Management, New Delhi, e) Illustrous Alumnus Award of Department of Pharmaceutical Sciences, Dr. H. S. Gour Vishwavidyalaya, Sagar, Diamond Jubilee Celebrations. He is the reviewer of various international journals.

Cite this article: Datta S, Patil S. Evaluation of Traditional Herb Extract Salvia officinalis in Treatment of Alzheimer's Disease. Pharmacog J. 2020;12(1):131-43. 